\title{
Between Spaces of Silence and Violence Re-Critiquing Doris Lessing's Anna Wulf from the Golden Notebook
}

\author{
M.Sarah Kamala Kumari ${ }^{1}$, S.Prasannasree ${ }^{2}$ \\ ${ }^{1}$ (Research Scholar (Part-Time), Department Of English', Andhra University, Visakhapatnam,India) \\ ${ }^{2}$ (Professor, Department Of English, Andhra University, Visakhapatnam,India)
}

\begin{abstract}
Doris Lessing holds a place of singular distinction in the history of post war English fiction. Described as the 'most fearless woman novelist in the world,unabashed ex-communist and uncompromising feminist. Lessing holds a unique place among twentieth century women writers for the sheer number,variety and scope of her work. Lessing is a writer in whose works the personal invariably merges with the political and the individual is seldom inseparable from the collective. Deeply rooted in the socio-political milieu of her time, Lessingwas nevertheless well ahead of her generation in many respects. 'The Golden Note Book'thus contains two strains. Politically it is a stark portrayal of communism, racial and sexual exploitation. Equally important, as these political actions, are the innermost feelings of the characters and their actions.
\end{abstract}

Keywords: Breakdown, Consciousness, Fragmentation, Free women, Notebooks,

Doris Lessing, born of British parents in Kermanshah, Persia,on October 22,1919,emigrated with her family to Banket in Southern Rhodesia at the age of five. She spent the most impressionable years of her life there, ventured into two abortive marriages and finally settled down in England in 1949. The years after Lessing's arrival in London witnessed a steady outpouring of books which included novels, short stories, science fiction, memoir, non-fiction and poetry. She began her literary career with novels about the growth of political awareness among the native blacks in colonized Africa. The experience of her African life provided the material of these early novels and stories.

Doris Lessing's novel, The Golden Notebook, published in 1962,acquired the status of the most considerable single work by an English author in the 1960's also which nourished the feminist movement and inspired a sexual revolution. Hailed as a key text of the feminist movement, The Golden Notebook became, very much like George Eliot's Middlemarch, a 'compendium of women's attitudes' but in an altogether different time. Breakdown is the central theme of The Golden Notebook and it is reflected in the novel's unconventional structure which accentuates the fragmentation of the protagonist's consciousness and the consequent formlessness of her life and writing. The theme is introduced at the very start with Anna's proclamation: "the point is ...that as far as I can see, everything's cracking up"(GNB:25) and is developed in a number of ways throughout the narrative. Anna Wulf is a former communist and a deeply leftist writer who lives in post-war London with her small daughter. A ' free woman' and an author of a successful first novel about the tragedy of colour-bar in colonial Africa, she is battling a writer's block and the damaging chaos of life. The commercial success of the novel provides Anna who is nearing forty, with a measure of financial freedom that enables her to bring up her daughter, do voluntary work for the British communist Party and muse on her past. She also spends a lot of time with an early Jungian psychotherapist, Mrs-Marks, who treats her for a growing ennui and a lack of feeling. Anna is Frozen(GNB:216) because she is afraid of death and destruction in the world:

It seems to me that ever since I can remember anything the real thing that has been happening in the world was death and destruction. It seems to me it is stronger than life.(GNB:216)

Anna's mental disorder mirrors the sickness of the world outside and this largely contributes to the breakdown. For fragmentation plagues Anna both as a woman and as a writer. The main reason for Anna's fragmentation is her experience of her own past. She has a brief neurotic but stupid involvement with Max Wulf, when she was staying in Africa and Janet is the child from that relationship.

Anna and Max Wulf were temperamentally and sexually incompatible. She married Max Wulf, whom she could never love and he repulsed her sexually, after Janet's birth they were divorced. She came to London with the child and the manuscript of he first novel, Frontiers of war. She became a celebrity after its publication. But her first literary success has proved a hindrance to her continued creativity. She also suffers from an awful feeling of disguise, of futility(GNB:55).Her depression is aggravated by the abrupt end of her love affair with Michael, a medical practitioner. Abandoned by her lover and unable to get over him, Anna feels frightened, vulnerable and sick. Disheartened by unsatisfactory relationships with men and increasingly disenchanted with communism. Anna -at-forty-feels her life is cracking up. Fragmentation torments her life, both at the personal 
and professional levels. Out of her fear of madness, she records her experiences into four different notebooksblack, red, yellow and blue:

As if Anna had almost automatically, divided herself into four, and then, from the nature of what she had written, named those divisions(GNB:71)

The Black notebook addresses Anna'a problems as a writer and records her African experience out of which she has written Frontiers of War. The Red notebook contains entries about her political life and chronicles her gradual disenchantment with communism. The Yellow notebook approaches Anna's relationships and emotions through the mode of fiction.

It is actually the draft of a novel entitled The shadow of the third in which Anna's heroine her alter-ego Ella re-enacts a substantial part of her experience. The blue notebook is a diary of everyday events and it provides a factual accounts of Anna's disappointing love-affairs with men, her motherhood, sexuality and mental states as well as her dreams and sessions with Mrs.marks .

The notebooks thus provide her with a means of ordering her life into neat categories both public and private. They track Anna's psychological movements through the past and the present. In doing so, Lessing keeps her finger on the pulse of an entire generation of mid twentieth century women who experienced unprecedented freedom as well as unprecedented confusion and tried to understand what this newly found freedom meant for them. In this connection Bergonzi writes

On the face of it Anna has achieved a degree of personal freedom that the new woman of Ibsen and Shaw could scarcely have dreamed of; she is as free as any man in all major spheres of life, professional, intellectual and above all, sexual.(Bernard Bergonzi:237).

In a brilliant act of verisimilitude, Anna alternates between the four notebooks instead of presenting each one as awhole. As a result, the narrative reads like a close transcription of actual experience. She also interlaces a short, conventional novel, entitled "Free woman", which examines her life from the omniscient narrators point of view. It deals with the problems and plight of emancipated women and reveals the precariousness of their freedom. Written after Anna's release from the writer's block the novel represents a creative re-shaping of Anna's fragmentated experience in the notebooks. Rose suggests that the parallel plots in Lessing's fiction represents, in Jungian terms, the rational ego and the unconscious (Ellen Cronan rose:74)

Anna's quest for freedom and integrated self-hood has political, psychological and sexual dimensions. Anna's attempt to get rid of her inner schism and attain a totality of vision is reflected in her desire to embrace communism. Explaining her decision to join the British communist party in early 1950s,she writes, somewhere at the back of my mind when I joined the party was a need for wholeness, for an end to the split, divided, unsatisfactory way we all live(GNB:157)

But it did not take her long to realize the yawning gap between Marxist theory and communist practice.The failure of Anna's political ideal, like her disappointing affairswith men, widens her inner rift which nothing,not even prolonged psychoanalytical treatment,can heal. The tremendous pressures of leading a schizophrenic life are combined with her frightening vision of the world leading towards destruction to expedite her mental breakdown. Anna is afflicted with an emotional void and a sense of ennui, and gradually moves away from sanity. She retreats more and more into silence since everything including language, seems devoid of meaning. With her disorientation from reality that slides into chaos and nullity, Anna's quest changes its direction. Through Psychological negotiations an exploration of the unconscious she seeks her release from Fragmented existence. In the 1960s, Lessing came under the spell of Psychoanalysis and Sufism. The Golden Note book reveals some of the major preoccupations of Jung an Laing like the unconscious, the link between the individual and the collective, dreams, neurosis, split self an insanity. A well - known disciple of Idries shar, Lessing has also incorporated into the novel the sufi concepts that:

The tendency to compartmentalize and artificially divide physical and mental reality is disruptive and Detrimental ------and that breaking is a necessary prerequisite for a new beginning (Alka Kumar : 38 and 47)

Anna recovers her mental health through erotic energy. Like D.H. Lawrence, Doris Lessing views sexuality as regenerative and she links her Protagonist's healing to sexual encounter which begins at a critical moment in her life. Janet becomes conscious of her mothers depression as well as the complicated atmosphere in their house and decides to go to a conventional boarding School. With her departure, Anna reverts to an order self-one who had not given birth to the child and begins to play a romantic as well as Parental role to a much younger lover, Saul green.

$\mathrm{He}$ is a roving American writer and disenchanted communist, comes to stay in her house for a brief period. With his naiveté, idealistic fervour, monstrous egoism, and self indulgence, Saul introduces Anna to a chaotic condition which is characterized by conflicting perceptions of life and reality. The weeks Anna spends with Saul in her flat become a terrible ordeal in which she takes on his madness:

The walls of this flat close in on us. Day after we are both mad.(GNB:502) Her rooms turn into a battleground where they confront each other without any disguise and play every imaginable man-women role.Through a marathon of sex, anger, jealousy and loneliness,(Margaret:44). 
Anna slowly recognizes her inner self. The concluding section of the blue note book records the cruel and self destructive hostility between these two crazy lovers which leads to a tremendous explosion of erotic energy that heals Anna and delivers her from fragmentation. She comes out of the Cocoon of madness(GNB:508) With a new kind of strength that enables her to confront reality confidently. With her release from the inner split, Anna abandons her dependence on compartmentalization that occasioned the four separate note books, and decides to put all of [herself] into one book. (GNB:528)

The Golden Note Book foregrounds the feminine point of view and thoroughly explores the issue of 'free women' that the critiques have labelled the novel a feminist text. In her conversation with Florence Howe, Lessing admitted that she did write from the women's point of view but than she was essentially writing about the right of the individual. (Florence Howe :34)

The inner Golden Notebook, which gives the novel its title and holds the key to Anna's mental recovery and creative renascence, suggests a movement away from fragmentation towards formlessness and fusion. In this notebook, which is written jointly by Anna and Saul, all divisions break down and the separate strands of the narrative come triumphantly together:

The film was now beyond my experience, beyond Ella's, beyond the notebooks, because there was a fusion, and instead of seeing separate scenes, people, faces, movements, glances, they were all together.(GNB:551)

After weeks of fierce psychological war and unbearable tension, Anna and Saul finally crack up. They come out of the 'Sadistic - masochistic cycle,' overcome their egocentric separatism, and break down into each other indistinguishably.

They recognize themselves in each other and mirror each other's moods and thoughts. They break through the false patterns and formulas they have made of their pasts to shore up themselves and each other: (GNB:7) Saul, who has been destructive of Anna, now supports and advises her. He forces her to overcome the writer's block and gives her the first sentence of her next novel, 'Free Women'. And Anna, who has been possessive and insanely envious, gives him her pretty new notebook, writing in it the opening sentence of her next book: On a dry hillside in Algeria, a Soldier watched the moonlight glinting on, his rifle. (GNB:556)

The healing care of a man thus enables Anna to recover from her mental breakdown. She decides to leave her big flat, where she feels desperately lonely and which always reminds her of Michael, and move to a smaller one. Meanwhile, Molly, too, has had an affair with a 'progressive' businessman and decided to marry him. Being tired of the emotional rat race (GNB:576) and aware of the hazards of an independent existence, she settles down to a life of togetherness based on mutual love and respect. On a close examination, however, the novel reveals - despite its pre-occupation with chaos and breakdown-a very tight structure and a brilliant control over fragmentation. Besides the colour, Lessing is concerned with the rights of a woman in a world of man and looks to the politics of the left-wing to bring justice to women and blacks alike.(Anthony Burgess: 99)

Although one of Lessing's principal concerns in the novel is to show the dangers of compartmentalized thinking, she constructs through this formalistic experimentation a coherent account of the life of her protagonist and the fractured world she inhabits. The book's final message is not fragmentation but unity. As she writes in the preface,

The essence of the book, the organization of it, everything ... says implicitly and explicitly, that we must not divide things off, must not compartmentalize.(GNB:10)

\section{References}

\section{Journal Papers:}

[1]. Cronan Rose, Ellen. "The end of the Game: New Direction in Doris Lessing's fiction," The Journal of Narrative Technique 6.1(1976 winter)

\section{Books:}

[2]. Bergonzi, Bernard. The Situation of the Novel (London: MacMillan,1970)

[3]. Kumar, Alka. Doris Lessing: Journey in Evolution. Book Plus, New Delhi 2001.

[4]. Howe, Florence. Doris Lessing's Free Women,Nation, Jan.11,1965

[5]. Burgess, Anthony The Novel Now (London: Faber and Faber, 1967).

[6]. Ghosh, Tapan Kumar. Doris Lessing's The Golden Notebook - A Critical Study, Prestige Books, New Delhi, 2006.

[7]. Rubenstein Roberta. The Novelistic Vision of Doris Lessing Breaking the Forms of Consciousness (1979; London: University of Illinois Press). 